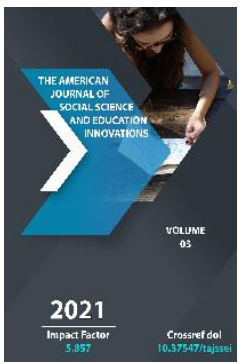

\title{
What Flipped Classroom Is And How It Works
}

\author{
Allanazarova Mamura Akhmedovna \\ Specialized Branch of Tashkent State University Of Law Department Of General Educational \\ Disciplines, Uzbekistan
}

Journal Website:

http://usajournalshub.c

om/index,php/tajssei

Copyright: Original content from this work may be used under the terms of the creative commons attributes 4.0 licence.

\section{ABSTRACT}

Nowadays there a great task is put before English teachers how to increase students' engagement in classroom activity participation to solve this problem many studies suggest implementing Flipped classroom. Let's have a look what the flipped classroom is. Flipping is an educational technique that is growing in popularity. Because flipping is a relatively new concept, it is likely to be foreign to students, who may view the practice as increasing their workload in comparison to traditional approaches.

\section{KEYWORDS}

Classroom, flipped, teachers, reverse, figure, analyzing, evaluating, students, education

\section{INTRODUCTION}

Samah Zakareya Ahmad lists different names from various empirical studies of the flipped classroom-sometimes called reverse, backwards, inverted, and upside down classroom-is an instructional model that inverts the traditional lecture-plus-homework format. [1] 
The American Journal of Social Science and Education Innovations (ISSN - 2689-100x)

Published: April 30, 2021 | Pages: 635-638

In a flipped classroom (FC), lectures are removed, and the removed content is often delivered to students through priceless input materials like video recordings. Students can study various types of materials (e.g., readings from a textbook and worksheets developed by their teacher) on their own outside of class time and grasp the meaning of the content. [2]

Mainly FC uses as a base the Bloom's Taxonomy (Figure1) below is given the reminder of it. We can see the hierarchy of how our brain works when receives information.

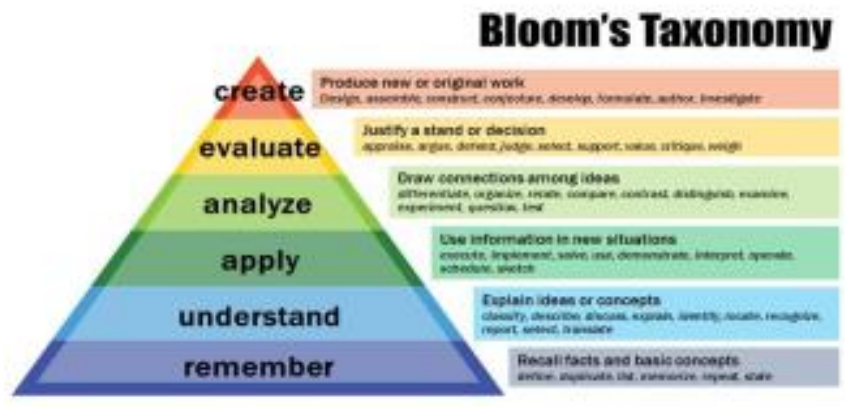

Figure 1. Bloom's Taxonomy hierarchy.

Now let's look what differences are between traditional and flipped model of teaching and how Bloom's taxonomy can be applied in the context of Flipped Classroom Model. (Figure 2)

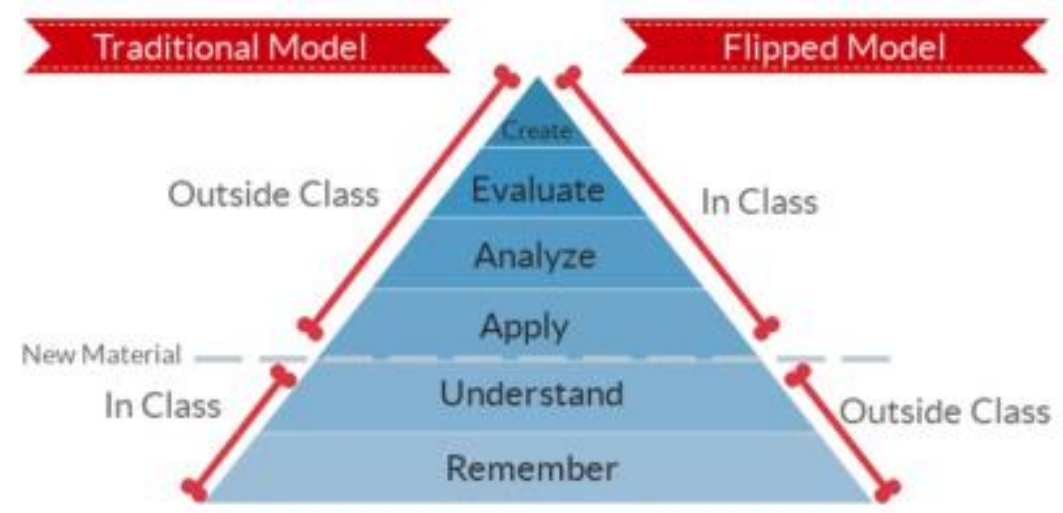

Figure 2. Application of Bloom's Taxonomy

By the looking at the Figure 2 we can see what happens in both classes. In traditional students are supposed to grasp the higher function in Bloom's hierarchy by themselves they don't have anyone to assist them if something is not clear however flipped model gives opportunity for students to discuss aroused questions in pre-class activity, moreover students are placed in question-answer environment where they can ask questions not only a teacher but their group mates. In Flipped classroom students learn and deep their skills in applying, analyzing, evaluating, and creating which are considered as complicated skills to develop. Consequently when students are focused on those skills they develop their critical and 
The American Journal of Social Science and Education Innovations

(ISSN - 2689-100x)

Published: April 30, 2021 | Pages: 635-638

creativethinking.

Possible scenarios:

\section{What Students Might Do At Home In A Flipped Classroom}

Watch an online lecture

Review online course material

Read physical or digital texts

Participate in an online discussion

\section{Perform research}

\section{What Students Might Do At School In A Flipped Classroom}

Skill practice (guided or unguided by teacher)

In-person, face-to-face discussion with peers

Debate

Presentations
Station learning

Lab experiments

Peer assessment and review

This doubles student access to teachers-once with the videos at home, and again in the classroom, increasing the opportunity for personalization and more precise guiding of learning. In the flipped classroom model, students practice under the guidance of the teacher, while accessing content on their own.[3]

In the flipped model, the time is completely restructured. Students still need to ask questions about the content that has been delivered via video, so we generally answer these questions during the first few minutes of class. This allows us to clear up misconceptions before they are practiced and applied incorrectly. The remainder of the time is used for more extensive hands-on activities and/or directed problem-solving time (see Table 1).[4]

\begin{tabular}{|l|c|l|l|}
\hline \multicolumn{2}{|c|}{ Traditional Classroom } & \multicolumn{2}{c|}{ Flipped Classroom } \\
\hline \multicolumn{1}{|c|}{ Activity } & Time & \multicolumn{1}{c|}{ Activity } & Time \\
\hline Warm-up activity & $5 \mathrm{~min}$. & Warm-up activity & 5 min. \\
\hline $\begin{array}{l}\text { Go over previous night's } \\
\text { homework }\end{array}$ & 20 min. & Q\&A time on video & $10 \mathrm{~min}$. \\
\hline Lecture new content & $\begin{array}{l}30-45 \\
\text { min. }\end{array}$ & $\begin{array}{l}\text { Guided and independent } \\
\text { practice and/or } \\
\text { lab activity }\end{array}$ & 75 min. \\
\hline $\begin{array}{l}\text { Guided and independent } \\
\text { practice and/or } \\
\text { lab activity }\end{array}$ & $\begin{array}{l}20-35 \\
\text { min. }\end{array}$ & & \\
\hline
\end{tabular}

Table 1. Comparison of Class Time in Traditional versus Flipped Classrooms.

Bergman and Sams implemented the flipped model for one year and they were pleased with how students were learning. They had evidence that their model worked and was better for kids. Therefore the results of current primary research in Nukus State Pedagogical Institute can be as one more evidence to support other studies around the world. The 
Flipped Classroom can address the needs of students by allowing teachers to personalize students education. You can do the same whether you teach math, science, social studies, language arts, physical education, ELL, a foreign language, or humanities.

\section{REFERENCES}

1. Carla B. Swearingen.(2016) Flipping the Syllabus: Using the First Day of Class To Encourage Student Acceptance of a New Pedagogical Technique in Muzyka and Luker; The Flipped Classroom Volume 1: Background and Challenges ACS Symposium Series; American Chemical Society: Washington, DC.

2. Samah Zakareya Ahmad .The Flipped Classroom Model to Develop Egyptian EFL Students' Listening Comprehension. English Language Teaching, 2016, Vol. 9, No. 9, pp.166-178

3. Lee Given \& Wallace Amanda. Flipped learning in the English as a foreign language classroom: Outcomes and Perception. TESOL Quarterly, 2018, Vol. 52(1), pp. 62-84

4. https://www.teachthought.com/learning/ the-definition-of-theflipped-classroom/

5. J. Bergmann and A. Sams (2012) Flip Your Classroom: Reach Every Student in Every Class Every Day; International Society for Technology in Education; ASCD: Eugene, OR, Alexandria, VA

6. Source figure 1. https://www.flickr.com/photos/vandycft/2 9428436431

7. Source figure 2. Bloom's Taxonomy in a Flipped Classroom (from site: https://www.odysseyware.com/blog/usin g-classpace-flipped-classroom)

8. Source table 1. J. Bergmann and A. Sams (2012) Flip Your Classroom: Reach Every Student in Every Class Every Day; International Society for Technology in Education; ASCD: Eugene, OR, Alexandria, VA 